\title{
PENERAPAN MODEL PEMBELAJARAN BERBASIS MASALAH UNTUK MENINGKATKAN HASIL BELAJAR PESERTA DIDIK KELAS XI-IPA3 SMAN 1 REJANG LEBONG
}

\author{
Rahayu Suci Agustina ${ }^{1 *}$, Irwandi Ansori ${ }^{1}$, Ariefa P.Yani ${ }^{1}$ \\ ${ }^{1}$ Program Studi Pendidikan Biologi, Fakultas Keguruan Dan Ilmu Pendidikan, Universitas Bengkulu \\ email: rahayusuciagustina@gmail.com
}

\begin{abstract}
Abstrak
Penelitian ini bertujuan untuk mengetahui aktivitas guru dan peserta didik serta hasil belajar peserta didik pada pembelajaran konsep sistem koordinasi dengan menerapkan Model PBL di kelas XI-IPA 3 SMAN 1 Rejang Lebong. Jenis penelitian adalah Penelitian Tindakan Kelas yang dilaksanakan dalam dua siklus. Subjek penelitian ini adalah guru biologi yaitu peneliti dan semua peserta didik kelas XI-IPA 3 SMAN 1 Rejang Lebong. Variabel penelitian ini adalah Model Pembelajaran Berbasis Masalah, aktivitas dan hasil belajar peserta didik. Instrumen penelitian terdiri dari lembar observasi dan lembar tes. Berdasarkan hasil penelitian yang dilakukan, pada siklus I skor aktivitas guru yaitu 26 tergolong kriteria baik, aktivitas peserta didik skor 25,5 tergolong kriteria baik, dan hasil belajar peserta didik yaitu 63,64\% tergolong kriteria belum tuntas. Pada siklus II skor aktivitas guru yaitu 27 kriteria baik, aktivitas peserta didik 27 kriteria baik, dan hasil belajar peserta didik mencapai $81,82 \%$ kriteria tuntas. Berdasarkan hasil penelitian disimpulkan bahwa pembelajaran dengan menerapkan Model PBL dapat meningkatkan aktivitas guru dan peserta didik serta hasil belajar peserta didik kelas XI-IPA 3 SMAN 1 Rejang Lebong pada konsep sistem koordinasi.
\end{abstract}

Kata Kunci: Aktivitas Siswa, Hasil Belajar, Pembelajaran Berbasis Masalah

\begin{abstract}
This study aims to determine the activities of teachers and learners and learning outcomes of learners on learning the concept of coordination system by applying the Model of PBL in class XI Sinces Major'3 of Senior High School 1 Rejang Lebong. The type of research is Classroom Action Research carried out in two cycles. The subject of this research is biology teacher that is researcher and all students of class XI Sinces Major'3 of Senior High School 1 Rejang Lebopng. The variables of this research are Problem Based Learning Model, Activity and Learning Results of Learners. The research instruments consist of observation sheets and test sheets. Based on the results of research conducted, in the first cycle of teacher activity scores are 26 good criteria, student activity score 25.5 good criterion, and the learning outcomes of learners is $63.64 \%$ criteria not yet completed. In the second cycle of teacher activity scores are 27 good criteria, the activities of students 27 good criteria, and students' learning outcomes reached $81.82 \%$ complete criteria. Based on the results of the study concluded that learning by applying the PBL Model can improve the activities of teachers and learners as well as the learning outcomes of students of class XI sinces Major'3 of Senior High School 1 Rejang Lebong on the concept of coordination system.
\end{abstract}

Keywords: Learning Outcomes, Student Activity, Problem Based Learning 


\section{PENDAHULUAN}

Peningkatan mutu pendidikan sangat berkaitan dengan pengetahuan yang didapat oleh manusia. Pada lingkungan sekolah, pengetahuan seorang peserta didik diukur dari hasil belajar peserta didik. Hasil belajar peserta didik tersebut diperoleh dari proses pembelajaran yang berlangsung antara guru dan peserta didik. Proses pembelajaran yang baik akan berdampak baik dengan hasil belajar peserta didik. Pada kenyataannya untuk mencapai hasil belajar yang diharapkan, masih ada peserta didik yang tidak aktif dalam proses pembelajaran. Belajarnya. Hasil belajar belum mencapai ketuntasan klasikal yang diharapkan oleh sekolah dan perlu dilakukannya peningkatan hasil belajar peserta didik

Berdasarkan hasil observasi dengan guru biologi SMA Negeri 1 Rejang Lebong, aktivitas belajar biologi peserta didik di kelas XI-IPA 3 masih tergolong rendah. Hal tersebut dikarenakan kurangnya partisipasi peserta didik dalam kegiatan pembelajaran. Banyak peserta didik yang diam, tidak aktif dan tidak dapat menjawab saat diberikan pertanyaan mengenai materi yang sedang dipelajari. Hasil belajar peserta didik kelas XI-IPA 3 cenderung lebih rendah diantara kelas yang lain. Hal ini ditandai dengan rendahnya nilai rata-rata hasil belajar biologi yang diperoleh peserta didik yaitu \pm 65 dengan ketuntasan minimal $\geq 75$.

Menanggapi permasalahan kelas XI-IPA 3 tersebut, peneliti menerapkan suatu model pembelajaran Model pembelajaran yang digunakan oleh peneliti yaitu model Pembelajaran Berbasis Masalah (Problem Based Learning). Pada model pembelajaran berbasis masalah berbeda dengan model pembelajaran yang lainnya, dalam model pembelajaran ini, peranan guru adalah menyodorkan berbagai masalah, memberikan pertanyaan, dan memfasilitasi investigasi. Melalui masalah tersebut peserta didik belajar keterampilan-keterampilan yang lebih mendasar dan dapat mengaitkannya dengan konsep materi yang diberikan oleh guru.
Penelitian ini bertujuan untuk mendeskripsikan aktivitas guru, peserta didik, dan hasil belajar peserta didik dengan menggunakan model pembelajaran berbasis masalah.

\section{METODE}

Jenis penelitian yang digunakan pada penelitian ini adalah penelitian tindakan kelas (PTK) dengam model deskriptif. Proses penelitian tindakan kelas ini menggunakan sistem spiral refleksi diri yang terdiri atas empat tahapan dimulai dengan perencanaan (planning), tindakan (acting), pengamatan (observasi) dan refleksi (reflecting) (Kusnandar, 2008).

Subyek dalam penelitian ini adalah guru dan peserta didik kelas XI-IPA 3 SMA Negeri 1 Rejang Lebong yang berjumlah 33 orang. Teknik pengumpulan data terdiri dari observasi dan tes. Instrumen penelitian yang digunakan adalah lembar observasi dan lembar tes. Analisis lembar observasi menggunakan 3 skala penelitian yaitu 3 (baik), 2 (cukup), 1 (kurang). Lembar tes yang digunakan terdiri dari 5 soal uraian. Hasil belajar peserta didik dianalisis dengan mencari rerata (Arikunto, 2010) sebagai berikut:

$$
X=\frac{\sum x}{N}
$$

Keterangan :

$X \quad$ : Nilai rata-rata siswa

$\Sigma \mathrm{X}$ : Jumlah nilai siswa

$N \quad$ : Jumlah siswa

Presentase Ketentuan Belajar Klasikal dapat dihitung dengan menggunakan rumus :

$$
K B=\frac{N}{S} \times 100 \%
$$

Keterangan :

KB : Ketuntasan Belajar Klasikal

$\mathrm{N} \quad$ : Jumlah siswa yang mendapat nilai $\geq 75$

S : Jumlah siswa (Arikunto, 2010) 


\section{HASIL DAN PEMBAHASAN}

\section{a. Aktivitas Mengajar Guru dan Belajar Peserta Didik}

Berdasarkan hasil penelitian yang telah dilakukan, diperoleh hssil penelitian yaitu aktivitas guru dan peserta didik yang dapat dilihat pada Tabel 1. Skor rata-rata diperoleh dari aktivitas mengajar guru pada siklus I yaitu 26, termasuk kriteria baik. Untuk aktivitass belajar peserta didik siklus I diperoleh rata-rata skor yaitu 25,5 termasuk kriteria baik. Aktivitas guru pada siklus II memperoleh skor 27 termasuk kategori baik. Pada aktivitas belajar peserta didik siklus II dieroleh skor sebesar 27, termasuk kategori baik.

Tabel 1. Aktivitas Mengajar Guru Dan Belajar Peserta Didik Siklus I dan Siklus II

\begin{tabular}{cccccc}
\hline \multirow{2}{*}{$\begin{array}{c}\text { No } \\
\text { Pengamat } \\
\text { (Observer }\end{array}$} & \multicolumn{2}{c}{$\begin{array}{c}\text { Aktivitas } \\
\text { Guru }\end{array}$} & \multicolumn{2}{c}{$\begin{array}{c}\text { Akttivitas } \\
\text { Belajar } \\
\text { Peserta Didik }\end{array}$} \\
\cline { 3 - 6 } & ) & $\begin{array}{c}\text { Siklu } \\
\text { s I }\end{array}$ & $\begin{array}{c}\text { Siklu } \\
\text { s II }\end{array}$ & $\begin{array}{c}\text { Siklu } \\
\text { s I }\end{array}$ & $\begin{array}{c}\text { Siklu } \\
\text { s II }\end{array}$ \\
\hline 1. & I & 26 & 27 & 26 & 27 \\
2. & II & 26 & 27 & 25 & 27 \\
Jumlah Skor & 52 & 54 & 51 & 54 \\
Rerata Skor & 26 & 27 & 25,5 & 27 \\
Kriteria Skor & Baik & Baik & Baik & Baik \\
\hline
\end{tabular}

\section{b. Hasil Belajar Peserta Didik}

Untuk hasil belajar siswa pada siklus I dan siklus II dapat dilihat pada Tabel 2 .

Tabel 2. Hasil Belajar Peserta Didik Siklus I dan Siklus II

\begin{tabular}{llllll}
\hline Siklus & $\begin{array}{l}\text { Jumlah } \\
\text { Peserta } \\
\text { Didik }\end{array}$ & $\begin{array}{l}\text { Rerata } \\
\text { Nilai } \\
\text { Akhir }\end{array}$ & $\begin{array}{l}\text { Yang } \\
\text { Mencapai } \\
\text { ketuntasan }\end{array}$ & $\begin{array}{l}\text { KBK } \\
\text { KBK }\end{array}$ & Kriteria \\
\hline I & 33 & 70,15 & 21 & $\begin{array}{l}63,64 \\
\%\end{array}$ & $\begin{array}{l}\text { Tidak } \\
\text { tuntas }\end{array}$ \\
\hline II & 33 & 75,30 & 27 & $\begin{array}{l}81,82 \\
\%\end{array}$ & Tuntas \\
\hline
\end{tabular}

Pada siklus I ketuntasan belajar klasikal peserta didik belum sepenuhnya tercapai dengan baik namun secara individu sudah sebagian besar peserta didik tuntas akan hasil belajar mereka. Hal ini dikarena sebagian besar peserta didik belum terbiasa dengan metode yang diterapkan oleh guru pada proses pembelajarannya.
Menurut Sanjaya (2008) kekurangan pembelajaran berbasis masalah (PBL) salah satunya adalah peserta didik tidak memiliki minat atau tidak memiliki kepercayaan bahwa masalah yang dipelajari sulit untuk dipecahkan, maka mereka enggan untuk mencoba. Sesuai dengan pernyataan tersebut peserta didik pada siklus I ini cenderung tidak termotivasi untuk terlibat dalam fenomena untuk memunculkan masalah dan hanya beberapa peserta didik yang aktif diawal pembelajaran bahkan ada peserta didik tidak fokus dalam pembelajaran. Hal tersebut disebabkan karena peserta didik hanya diberikan beberapa pertanyaan untuk memunculkan masalah pada sintaks tersebut.

Pada siklus I guru membimbing peserta didik dalam pembagian kelompok sedangkan peserta didik membentuk kelompok. Pembagian kelompok secara heterogen yaitu setiap kelompok terdiri dari laki-laki, perempuan, dan kemampuan yang berbedabeda. Pengelompokkan peserta didik dilakukan untuk setiap anggota peserta didik dapat melakukan metode diskusi. Rusman (2011) menyatakan bahwa diskusi kelompok merupakan suatu proses yang teratur yang melibatkan sekelompok orang dalam interaksi tatap muka yang informal dengan berbagai pengalaman atau informasi, pengambilan kesimpulan atau pemecahan masalah.

Adapun kelebihan dari metode diskusi ini menurut Djamarah (2000) salah satunya adalah mendorong peserta didik untuk berpendapat secara bebas. Dari pernyataan tersebut menunjukkan kelompok diskusi sangat efektif untuk dilakukan dalam pembelajaran terutama dalam hal memecahkan masalah karena peserta didik cenderung lebih bisa bertukar pendapat dan informasi yang sesuai dengan permasalahan yang disajikan.

Pada siklus I guru membimbing peserta didik secara berkelompok dengan mengecek ke setiap kelompok diskusi agar peserta didik lebih mudah mendapatkan informasi yang sesuai dengan pemecahan masalah. Menurut Arends (2009) Implementasi PBL ditandai oleh adanya kerja sama antar siswa satu sama lain, 
biasanya dalam pasangan siswa atau kelompok kecil siswa. Bekerja sama akan memberikan motivasi untuk terlibat secara berkelanjutan dalam tugas-tugas yang kompleks, meningkatkan kesempatan untuk saling bertukar pikiran dan mengembangkan inkuiri, serta melakukan dialog untuk mengembangkan kecakapan sosial.

Selanjutnya, guru mengecek setiap kelompok tidak hanya satu peserta didik saja tetapi, mengecek setiap pekerjaan yang dilakukan oleh peserta didik untuk aktif memecahkan masalah mengenai hormon pertumbuhan dan perkembangan remaja sampai mengenai penyakit pada sistem endokrin. Menurut Cahyo (2013) model pembelajaran berbasis masalah merupakan sebuah model pembelajaran yang berdasarkan permasalahan dan didominasi oleh siswa (students center) dan dicirikan adanya keterbukaan, proses demokrasi, dan peran aktif siswa.

Keseluruhan proses yang terjadi dalam pelaksanaan berdasarkan masalah diharapkan dapat membantu siswa untuk memilki kemandirian, percaya pada keterampilan intelektual yang dimiliki siswa, dan keterlibatan aktif dalam proses inkuiri. Menurut Sani (2014) mengemukakan bahwa Problem Based Learning (PBL) akan dapat membantu siswa untuk mengembangkan keterampilan berpikir dan mengatasi masalah.

Berdasarkan beberapa pendapat mengenai definisi pembelajaran berbasis masalah tersebut dapat disimpulkan bahwa keaktifan siswa dalam memecahkan suatu masalah terutama masalah kehidupan nyata sebagai pembelajaran oleh siswa untuk melatih dan meningkatkan keterampilan berpikir kritis dan pemecahan masalah dan dapat mengetahui konsep-konsep penting.

Guru membimbing peserta didik merencanakan dan menyiapkan hasil karya berupa laporan lembar diskusi yang diberikan oleh guru pada peserta didik namun, pada tahap ini penyajian hasil karya yang telah dibuat oleh peserta didik tidak seluruh kelompok dapat menyajikannya didepan kelas. Hal tersebut dikarenakan alokasi waktu yang tidak cukup untuk seluruh kelompok menyajikan hasil karya di depan kelas. Sehingga hanya ada dua kelompok yang dapat menyajikan hasil karyanya di depan kelas.

Sanjaya (2011) menyatakan kelemahan pembelajaran berbasis masalah yaitu keberhasilan dari suatu pembelajaran problem based learning membutuhkan waktu yang cukup lama untuk persiapan sampai proses pembelajaran dilaksanakan. Alokasi waktu dalam proses pembelajaran harus diperhatikan untuk setiap tahapan pembelajaran agar semua tahapan dapat dilakukan secara baik dan pembagian waktu untuk setiap tahapnya menjadi cukup. Beberapa hal yang menjadi hambatan pada siklus I tersebut di evaluasi oleh guru pamong dan peneliti untuk perbaikan pada siklus II.

Pada siklus II Terdapat peningkatan jumlah peserta didik yang mencapai ketuntasan yaitu 27 orang dengan rerata nilai 75,30 . Nilai presentase pada siklus II mencapai $81,82 \%$ dan termasuk dalam kriteria tuntas. Hal ini dikarenakan sebagian besar peserta didik sudah terbiasa dengan metode yang diterapkan oleh guru selama ini sehingga proses pembelajaran yang berlangsung lebih kondusif sesuai dengan sintaks atau tahapan pembelajaran dan berdampak pada meningkatnya hasil belajar peserta didik. Dalam proses pembelajaran kegiatan belajar mengajar, perubahan terhadap aspek-aspek intelektual, emosional atau sikap (keterampilan) akan dapat terlihat dalam bentuk hasil belajar.

Winkel (2007) menyatakan hasil belajar adalah setiap macam kegiatan belajar menghasilkan perubahan yang khas yaitu, belajar. Hasil belajar tampak dalam suatu prestasi yang diberikan siswa, misalnya menyebutkan huruf dalam abjad secara berurutan. Hasil belajar merupakan kemampuan, keterampilan, dan sikap seseorang dalam menyelesaikan suatu hal. Hasil suatu pembelajaran (kemampuan, keterampilan, dan sikap) dapat terwujud jika pembelajaran (kegiatan belajar mengajar) terjadi (Arifin, 2000). 
Baik individu ataupun tim, menginginkan suatu pekerjaan dilakukan secara baik dan benar agar memeperoleh hasil yang baik dari pekerjaan tersebut. Keberhasilan ini akan tampak dari pemahaman, pengetahuan atau keterampilan yang dimiliki oleh individu ataupun tim.

Menurut Bloom dan ditulis kembali oleh Sudjana (2001), secara garis besar membagi hasil belajar menjadi tiga ranah, yaitu : 1) Ranah kognitif berkenaan dengan hasil belajar intelektual yang terdiri dari enam aplikasi, analisis, sintesis, dan evaluasi. 2) Ranah afektif berkenaan dengan sikap yang terdiri dari lima aspek yaitu penerimaan, jawaban, penilaian, organisasi, dan internalisasi. 3) Ranah Psikomotorik berkenaan dengan hasil belajar berupa keterampilan dan kemampuan bertindak Berdasarkan teori-teori diatas dapat disimpulkan bahwa hasil belajar adalah hasil yang diperoleh seseorang dalam proses kegiatan belajar mengajar, dan hasil belajar tersebut dapat berbentuk kognitif, afektif, dan psikomotorik yang penilaiannya melalui tes.

Media yang digunakan berupa video juga mempengaruhi proses pembelajaran. Penanyangan video yang singkat membuat para peserta didik lebih fokus dan memahami konsep pembelajaran pada sub materi NAPZA dan pengaruhnya pada sistem saraf. Pada siklus II yang telah dilakukan, pembagian waktu yang tepat sesuai dengan jam pelajaran untuk setiap sintaks pembelajaran. Hal tersebut membuat waktu pengerjaan post test tepat waktu dan sesuai durasi yang telah ditentukan. Menurut Fauzi (2014) Pembelajaran berbasis masalah dapat meningkatkan hasil belajar peserta didik. Pernyataan tersebut sesuai dengan hasil penelitian peneliti dimana terjadi peningkatan presentase ketuntasan dan nilai rata-rata peserta didik.

Peningkatan hasil belajar peserta didik juga didukung dengan aktivitas pembelajaran antara guru dan pesera didik. Semakin baik proses pembelajaran semakin baik pula hasil belajar peserta didik. Hal tesebut sesuai dengan Utomo (2014) yang menyatakan hasil belajar peserta didik dipengaruhi oleh proses selama pembelajaran.

\section{PENUTUP}

\section{Kesimpulan}

Dari hasil penelitian yang telah dilakukan dapat disimpulkan bahwa :

1. Penerapan model pembelajaran berbasis masalah di kelas XI-IPA 3 SMAN 1 Rejang Lebong dapat meningkatkan aktivitas belajar guru maupun peserta didik.

2. Penerapan proses pembelajaran dengan menerapkan model pembelajaran berbasis masalah di kelas XI-IPA 3 SMAN 1 Rejang Lebong pada pokok bahasan sistem koordinasi dapat meningkatkan hasil belajar biologi peserta didik.

\section{Saran}

1. Bagi Peneliti sebaiknya dapat mengatur waktu jalannya proses pembelajaran karena proses pembelajaran dengan menerapkan model pembelajaran berbasis masalah ini memerlukan ketepatan waktu dalam setiap sintaksnya.

2. Bagi peneliti dan guru sebaiknya dapat diperhatikan untuk media pembelajaran yang digunakan sebagai sarana penunjang bagi peserta didik untuk meningkatkan aktivitas belajar pada peserta didik.

3. Harapan peneliti untuk penelitian selanjutnya guru dapat menerapkan model pembelajaran berbasis masalah sebagai alternatif pada materi pembelajaran biologi yang lainnya.

\section{Daftar Pustaka}

Arends, Richard. 2009. Learning to Teach: Belajar untuk Mengajar. Buku Dua. (Penerjemah: Helly Prayitno Soetjipto dan Sri Mulyantini Soetjipto). Pustaka Pelajar.Yogyakarta.

Arifin. 2000. Strategi Belajar Mengajar. Jurusan Pendidikan Kimia FPMIPA UPI. Bandung.

Arikunto, Suharsimi. 2006.Penelitian Tindakan Kelas. Jakarta: PT Bumi Aksara. 
Djamarah dan Zain. 2006. Strategi Belajar Mengajar. Jakarta: PT Asdi Mahasatya.

Djuwita, Ita. 2012. Pertumbuhan dan Sekresi Protein Hasil Kultur Primer Sel-Sel Serebrum Anak Tikus. Jurnal Veteriner. Vol 13 (2): 125-135.

Fauzi, Rohmad, dkk. 2014. PENINGKATAN HASIL BELAJAR SISWA MELALUI MODEL PROBLEM BASED LEARNING. Lampung: Jurnal Edukasi UNILA.

Kunandar. 2008. Langkah Muda Penelitian Tindakan Kelas Sebagai Pengembangan Profesi Guru. Jakarta: Raja Grafindo Persada.

Rusman. 2011. Model-Model Pembelajaran Mengembangkan Profesionalisme Guru. Jakarta: PT. Raja Grafindo Persada.

Sanaky, Hujair. 2009. Media Pembelajaran. Yogyakarta: Safira Insania Press

Sanjaya, Wina. 2011. Penelitian Tindakan Kelas. Jakarta: Kencana Prenada Media Group

Sanjaya, Wina. 2006. Strategi Pembelajaran. Jakarta: Kencana Prenada Media Group.

Sudjana, N. 2004. Dasar-Dasar Proses Belajar Mengajar. Bandung: Sinar Baru Algensindo.

Utomo, Tomi dkk. 2014. Pengaruh Model Pembelajaran Berbasis Masalah (Problem Based Learning) Terhadap Pemahaman Konsep dan Kemampuan Berpikir Kreatif Siswa (Siswa Kelas VIII Semester Gasal SMPN 1 Sumbermalang Kabupaten Situbondo Tahun Ajaran 2012/2013 Jember.: JURNAL EDUKASI UNEJ 2014, I (1): 5-9

Winkel, W. S. 2007. Psikologi Pembelajaran. Yogyakarta: Media Abadi 